Krsta Brčcé,
dipl. inž.

Tehnicki opitni centar KoV.

Beograd
PRIMER SISTEMA ZA UPRAVLJANJE OPREMOM NA AUTOMATIZOVANIM VEŽBOVNIM POLIGONIMA NA BAZI PROGRAMABILNIH KONTROLERA I PERSONALNOG RAČUNARA

UDC: $623.593: 65.011 .56: 681.322$

\title{
Rezime:
}

$U$ članku se razmatra primena PLC modula povezanih sa personalnim računarom za realizaciju sistema za upravljanje opremom na automatizovanim vežbovnim poligonima. PLC moduli su projektovani za nepovoljne uslove radne sredine $u$ industrijskim pogonima. Personalni računar može biti osnova za rešavanje najrazličitijih problema automatskog upravljanja. Tako nastaju ekonomicna rešenja sistema za nadzor i upravljanje. Radi ilustracije prikazan je primer sistema za upravljanje metama na pešadijskom strelištu.

Ključne reči: sistem za upravljanje, personalni računar, programabilni kontroler, vežbovni poligon, upravljanje metama.

\section{EXAMPLE OF A PC-PLC BASED EQUIPMENT CONTROL SYSTEM IN AUTOMATED TRAINING AREAS}

\section{Summary:}

The topic of this paper is using the programmable logic controller (PLC) connected with $a P C$ in order to control equipment in training areas. PLCs are typically designed to withstand high amounts of impact and vibration in industry. Personal computer technology is an extraordinary powerful platform for innovators in finding the solution to the problem of automatic control. Such systems can provide economical fullfeatured monitoring and control solution. In order to explain the problem, we will show one example of a target control system in an infantry training area.

Key words: control system, personal computer, programmable logic controller, infantry training area, target control system.

\section{Uvod}

Danas se u velikom broju industrijskih pogona već masovno koriste sistemi i elementi sistema za upravljanje procesima na bazi mikroprocesorskih modula, odnosno industrijskih računara modularne strukture. Ranih osamdesetih godina otpočela je značajna upotreba programabilnih logičkih kontrolera (PLC Programming Logic Controller) $\mathrm{u}$ industrijskim pogonima. Prvobitno namenjeni da zamenjuju složene relejne sklopove, danas su dostigli takav nivo razvoja da obavljaju veoma složene funkcije obrade procesnih veličina, kontrole i komunikacije sa drugim uređajima u sistemu upravljanja industrijskim procesima. Ovi uređaji dostigli su masovniju primenu zahvaljujući tome što koriste elemente arhitekture mikroračunara tako da imaju modularnu hardversku strukturu, veoma su robustni, otporni na vibracije i prljavštinu. U vrlo velikom broju slučajeva (do $80 \%$ ) oni zadovoljavaju složene zahteve jednog kola kontrole, a preko modula za 
komunikaciju mogu se povezivati sa nadređenim delovima sistema (a to mogu biti personalni računari - PC). Zapravo, PC su već više od dvadeset godina u sistemima za upravljanje industrijskim postrojenjima i procesima, a zbog pogodnih karakteristika (npr. vizuelnih prikaza) pokazali su se dovoljno dobrim u sistemima upravljanja, naročito sa stanovišta rada operatora. Danas PC imaju brojnu hardversku i softversku podršku za najrazličitije primene, kao i mogućnost za komercijalnu i profesionalnu komunikaciju sa mnogo uređaja (standardizacija na nivou komunikacije i primene sistemskog softvera). Može se reći da je izražena potreba za upravljanjem industrijskim procesima primenom PC računara uz dodatke koji su prilagođeni objektu upravljanja (kao što su PLC moduli). Na taj način PC zamenjuju specijalne i skupe računare, a, zahvaljujući dobrim karakteristikama, hardverskoj i softverskoj podršci velikog broja proizvođača, čine dobru osnovu za savremene merno-upravljačke sisteme [1]. Moguce je da se primenjuju za tehničke sisteme na vežbovnim poligonima koji se mogu uporediti sa industrijskim pogonima (ne samo po strukturi i funkciji, već i prema radnim uslovima okoline). Radni uslovi mogu biti, u nekim slučajevima, odlučujući za izbor tipa procesne opreme. PLC su projektovani za rad u teškim radnim uslovima, a PC može biti u komandnoj prostoriji i nije neophodno da bude posebno prilagođen industrijskim uslovima rada.

Danas mnogi proizvođači nude opremu $[7,8]$, tehnička rešenja i programske pakete za nadzor i upravljanje procesima, koji podržavaju veliki broj raspoloživih programabilnih kontrolera $\mathrm{i}$ omogućavaju priključenje druge opreme vodecih svetskih proizvođača. Pored osnovnih funkcija prikupljanja podataka i upravljanja, ova oprema ima i mogućnost povezivanja u mrežu, sekvencijalno vođenje, statistički nadzor, vremensko izvođenje programa, PID regulacije, uvođenje dodatnih korisničkih programa i drugo.

\section{Definisanje problema}

Ukoliko se posmatraju postupci markiranja i imitacije koji se izvode na poligonskim vežbama u osnovnoj jedinici (tabela 1), može se uočiti da se radi o kompleksnim nastavnim aktivnostima koje se izvode uz pomoć složenih tehničkih sredstava.

Markiranje je nastavna aktivnost kojom se na terenu predstavlja i obeležava raspored snaga suprotne strane, simuliraju aktivnosti, radnje i postupci suprotne strane uz pomoć meta, lutki, maketa (oruđa, borbenih i neborbenih vozila), silueta aviona i helikoptera, uređaja za upravljanje metama i dr. Imitacijom se docarava dejstvo sopstvenih borbenih sredstava, ali i sredstava suprotstavljene strane. Svako korišceno sredstvo, tj. komplet opreme, ima jasno definisane fizicke elemente, funkcije, relacije i uslove koji čine sistem, a njime se upravlja kako bi se ostvarila namena. Dakle, postoji sve ono što definiše pojam upravljanog sistema (mehanička kretanja, detekcija stanja, detekcija događanja, razna dejstva i efekti), tj. procesa koji se može opisati matematičko-logičkim relacijama. Isto tako, može se uočiti da se vrši upravljanje uređajima korišcenih tehničkih sredstava (ručno, programirano, itd.). Kod svakog od kompleta opreme, ako je predviđen da bude upravljan, može se prepoznati: komandni pult KP (ili komandni uređaj $\mathrm{KU}$ ) i uređaji kojima se 
Markiranje i imitacija na vežbama

\begin{tabular}{|c|c|c|c|c|c|}
\hline \multicolumn{3}{|c|}{ Markiranje } & \multicolumn{3}{|c|}{ Imitacija } \\
\hline $\begin{array}{l}\text { Vreme } \\
\text { izvodenja }\end{array}$ & $\begin{array}{c}\text { Način } \\
\text { organizovanja }\end{array}$ & $\begin{array}{l}\text { Upotrebljena } \\
\text { sredstva }\end{array}$ & $\begin{array}{l}\text { Odnos } \\
\text { snaga }\end{array}$ & $\begin{array}{c}\text { Način } \\
\text { izvođenja }\end{array}$ & $\begin{array}{l}\text { Upotrebljena } \\
\text { sredstva }\end{array}$ \\
\hline $\begin{array}{l}\text { 2. Noću } \\
\text { 3. Kombinovano }\end{array}$ & $\begin{array}{l}\text { 1. Linijski } \\
\text { 2. Prostorno } \\
\text { 3. Kombinovano }\end{array}$ & $\begin{array}{l}\text { 1. Lutke } \\
\text { 2. Makete } \\
\text { 3. Siluete } \\
\text { 4. Komplet opre- } \\
\text { me peSadijskog } \\
\text { strelista (KOPS) } \\
\text { 5. Komplet opre- } \\
\text { me radio stre- } \\
\text { lista (KORS) }\end{array}$ & $\begin{array}{l}\text { 1. CVG-BVG } \\
\text { 2. CPOG-CPOG }\end{array}$ & $\begin{array}{l}\text { 1. Na cilju } \\
\text { 2. Na vatre- } \\
\text { nom polożaju } \\
\text { 3. Kombinovano }\end{array}$ & $\begin{array}{l}\text { 1. Imitator dejstva } \\
\text { artiljerijskih } \\
\text { oruda IDAOM87 } \\
\text { 2. Imitator nuklearne } \\
\text { eksplozije INE M78 } \\
\text { 3. Imitator hemijskog } \\
\text { udara IHU BM78 } \\
\text { 4. Imitator } \\
\text { IZBS M4 }\end{array}$ \\
\hline
\end{tabular}

upravlja (za simulaciju borbenog poretka, pokretanje meta i silueta, imitaciju efekta vatre, itd.). Pored toga, na pultovima postoji signalizacija stanja uređaja. Upravljanje ovom opremom može se posmatrati kao centralizovan sistem za prikupljanje podataka, nadzor, praćenje i upravljanje procesa sa prostorno raspoređenim elementima.

Elementi za pokazivanje stanja (senzori, merači, davači i sl.) i izvršni uređaji čine primarne delove sistema i nalaze se uz sam proces koji se prati i upravlja. Prikupljanje podataka i upravljanje, za prostorno raspoređene uređaje koji čine funkcionalnu celinu, vrši se centralizovano $-\mathrm{s}$ jednog mesta. Prostorno raspoređeni delovi sistema mogu da imaju, i korisno je da imaju, pored mernih elemenata, davača signala i pogona (napr. elektromotorne), i pojedine delove sistema za upravljanje, tj. pojedini delovi sistema za upravljanje treba da budu postavljeni „uz sam proces" kojim se upravlja sa centralnog mesta.

Komplet opreme pešadijskog strelista (KOPS) jedan je od kompleta opreme iz skupa sredstava za markiranje koji će se razmatrati kao objekat sistema za upravljanje, uz ukazivanje na jedno od mogucih rešenja problema upravljanja primenom programabilnih kontrolera i personalnog računara. KOPS se sastoji od prostorno raspoređenih uredaja za pokretanje meta i indikaciju, kojima se upravlja sa komandnog pulta (slika 1).

\section{Prikaz mogućeg rešenja}

Komplet opreme pešadijskog strelišta sa funkcijama pokretanja meta i pokazivanja pogodaka treba da se nadzire i upravlja sa komandnog pulta. Postojeći sistem KOPS-a je zastareo. Kao novo rešenje sistema za upravljanje ovim sredstvom razmatraće se primena PLC i personalnog računara. Pri tome se neće analizirati optimalnost izabranog rešenja već samo njegova pogodnost kao eventualno prihvatljivo rešenje. Takvim rešenjem bi se dobio savremen sistem za nadzor, praćenje i upravljanje, kakav se danas koristi u mnogim industrijskim pogonima. Dakle, koristili bi se PLC, kao dislocirani upravljački uređaji (predviđeni za rad u poljskim uslovima) i PC koji je smešten u delimično zaštićenim uslovima okoline, kao centralni upravljački uređaj 


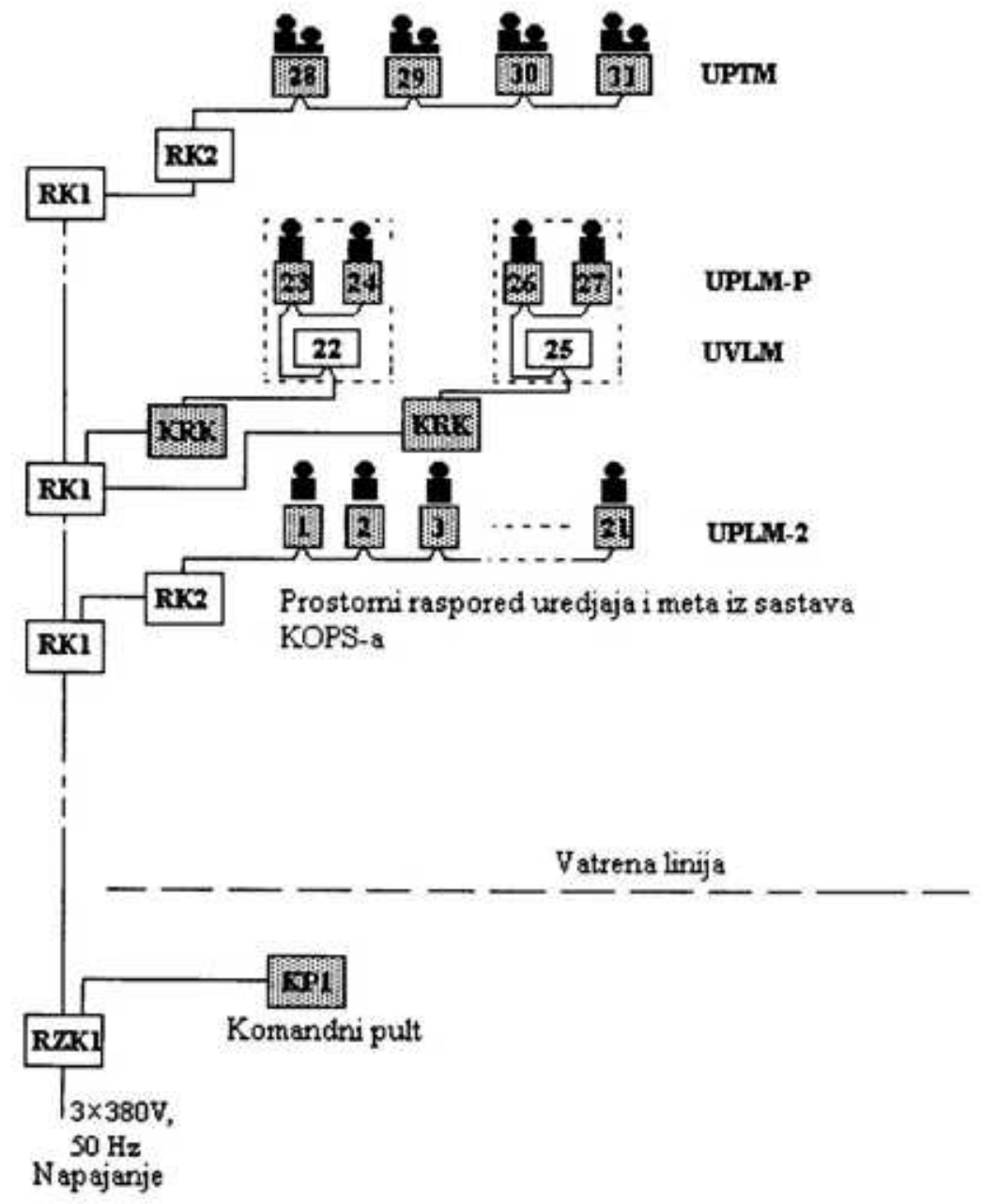

SI. 1 - Komplet strelišne opreme KOPS:

KP - komandni pult, RZK - razvodno-zaśtitna kutija, UPLM-2 - uređaji za pokazivanje lakih meta, UVLM - uredaji za vucu lakih meta, UPLM-P - uređaji za pokazivanje lakih meta koji se postavljaju na UVLM, UPTM - uredaji za pokazivanje teకkih meta, RK1 - razvodna kutija 1 , RK2 - razvodna kutija 2, KRK - komandno-razvodna kutija

sa odgovarajucim dodacima. Takav sistem omogućavao bi operatoru jednostavan nadzor procesa, razne intervencije $\mathrm{i}$ eventualnu vezu sa drugim sličnim ili istim sistemima.

$\mathrm{U}$ daljem tekstu dat je kraci prikaz PLC kontrolera i personalnih računara u sistemima za upravljanje.
Programabilni kontroler i personalni računar u sistemima za upravljanje

Programabilni kontroleri su od samog pocetka bili projektovani za industrijsku primenu (rubustni u pogledu mehaničke izdržljivosti, nemaju memoriju sa pokretnim delovima, imaju precizno 


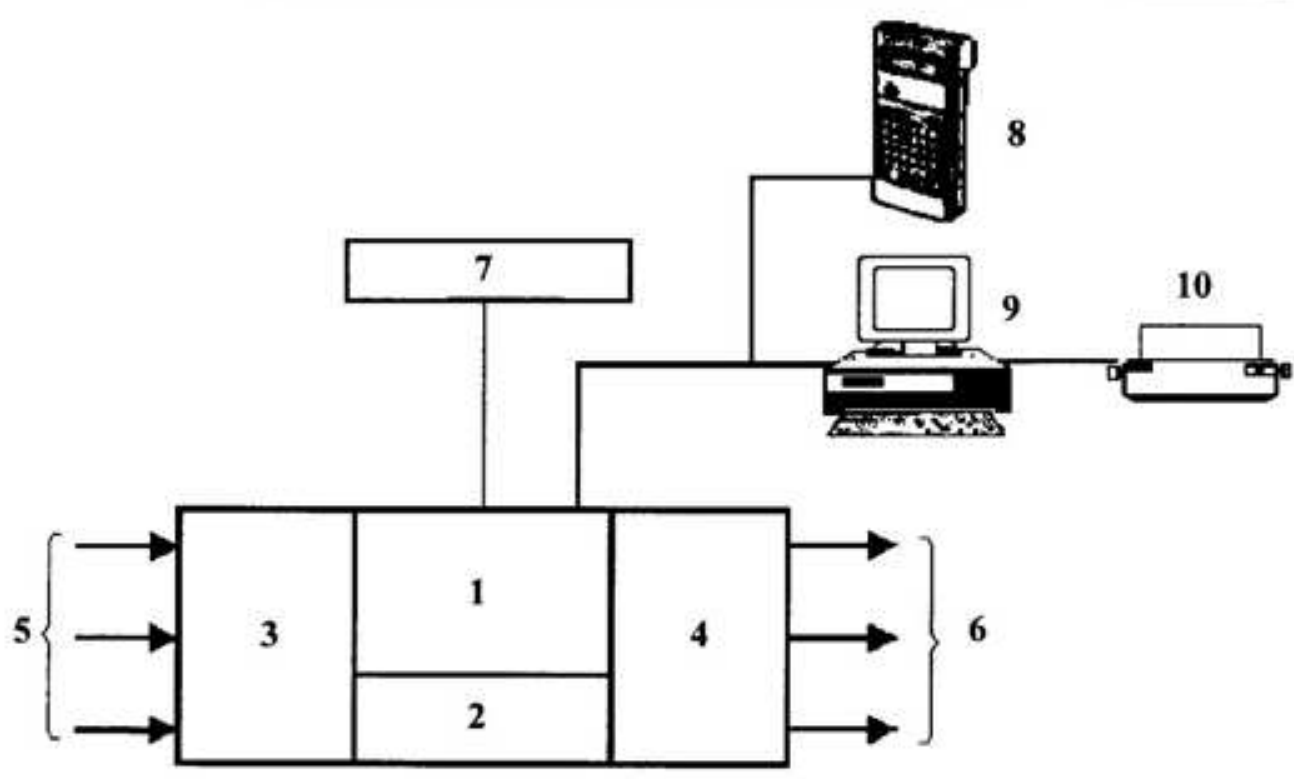

Sl. 2 - Blok-šema programabilnog kontrolera:

1 - procesor, 2 -memorija, 3 - ulazni međusklop, 4 - izlazni međusklop, 5 -signali od prekidaća, senzora i drugih davaca,

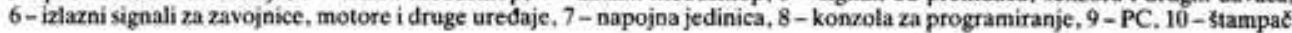

definisane funkcije pri „hladnom i vrucem restartu“) i obično funkcionišu u tzv. realnom vremenu, imaju specifične dijagnostičke funkcije i dr. Uvođenjem programabilnih kontrolera nije promenjena logika rešavanja problema automatizacije industrijskih procesa, ali je njihovo korišćnje olakšalo realizaciju i skratilo vreme potrebno za realizaciju zadataka automatizacije. Njihova odlika je da se relejne šeme realizuju programski, pri čemu je zadržana logika relejne seme, a uz to može da sadrži i druge elemente sistema za upravljanje.

PLC se sastoji od centralne procesorske jedinice, memorije, električnih kola za prijem podataka, električnih kola za slanje podataka i dodatnih električnih kola (slika 2).

PLC se može posmatrati kao kutija ispunjena relejima, brojačima, generatorima vremenske baze i memorijskim pro- storom, pri čemu većina ovih komponenti, kao što su releji fizički ne postoje već su softverski simulirani. Uređaj kao celina funkcioniše tako što se neprekidno izvršava program: očitavanje ulaznih stanja (podataka), izvršavanje programiranih instrukcija i upisivanje izlaznih stanja (podataka na osnovu kojih se deluje na elektromotorne i druge pogone upravljačkog sistema). To se ciklično ponavlja, pri čemu trajanje ciklusa zavisi od brzine $\mathrm{i}$ sastava PLC, a kreće se od nekoliko $\mu$ s i manje do nekoliko milisekundi i više. Naravno, postoji i niz drugih funkcija, kao što su komunikacije sa drugim kontrolerima i dr.

$\mathrm{U}$ današnjim uslovima PLC može biti povezan sa PC (slika 2). Pri tome PC može poslužiti kao konzola za programiranje, ali i kao nadređeni kontroler. Naime, ako je (a u ovom primeru to jeste), pored samo upravljackih zadataka, po- 
trebno obavljati i druge funkcije, kao što su obrada podataka, umrežavanje i vizuelni prikazi, treba projektovati sistem za upravljanje na bazi PC (PC-based Control), što posebno važi ako je već na raspolaganju personalni računar (po mogućstvu u industrijskoj izvedbi), a raspoloživi operativni sistem Windows 95,98 ili NT. Programiranje upravljačkog algoritma može se izvesti uz korišćenje nekog od viših programskih jezika ili programskog jezika za PLC koji radi na PC. Treba pomenuti da upravljanje na bazi personalnog računara nije isto što $i$ upravljanje pomoću personalnog računara koji sadrži programabilne kontrolere u obliku dodatih PCI kartica. Inače, u praksi se mogu sresti sledece kombinacije:

- personalni računar vrši kompletno upravljanje,

- programabilni kontroler povezan sa programabilnim pokazivačem i konzolom vrši kompletno upravljanje,

- personalni racunar ima ulogu centralnog uređaja, a dislocirane funkcije uprayljanja vrše programabilni kontroleri.

Softverska podrška za programabilne kontrolere $i$ personalne računare u sistemima za upravljanje

Program za rad, tj. relejna sema programabilnog kontrolera može se uneti u memoriju kontrolera na više načina. Jedan od načina je da se unosi preko konzole (tastature) za programiranje, koja ima ulogu linijskog editora, sa ugrađenim protokolom za komunikaciju. Za kodiranje relejne šeme u obliku programskih simbola (mnemonička) postoje pravila koja pokrivaju sve strukture dijagrama. Ipak, kod programa sa složenim grananjem šeme, to prevođenje može biti složeno, a zbog nepreglednosti programa moguće su i greške koje je teško otkriti. $\mathrm{Za}$ ovo se mogu koristiti standardni programski jezici (ASSEMBLER, C, itd.), ali su razvijeni i posebni programski jezici i programski paketi koji mogu biti (prema IEC 1131) u obliku teksta, kao što su liste instrukcija (IL - Instruction List) i struktuiranog teksta (ST - Structured Text), ili grafičkih simbola električnih kola sa relejima (Ladder Diagram - LD), simbola sekvencijalnih kola (SFC - Secquential Function Chat) i funkcionalnog blok-dijagrama (FBD - Function Block Diagram).

Proizvođači, od kojih su kod nas najzastupljeniji Siemens i Omron, nude programske pakete za programiranje programabilnih kontrolera i izradu računarskih programa za upravljanje, praćenje i nadzor industrijskih procesa, koji rade pod DOS-om ili pod WINDOWS okruženjem. Organizacija programa je u obliku blokovskih struktura uz mogućnost pisanja komentara, tako da se može deliti na logičke celine. Standardne „clipboard“ procedure manipulacije ovim blokovima, kao i kompletnim programima olakšavaju rad (inicijalizacija kontrolera, programiranje reakcije na sistemske alarme i sl.). Softverski alati za sastavljanje i pisanje programa za upravljanje procesima, kao i alati za ostale operacije, omogućavaju pristup iz menija, a na ekranu postoje i paneli sa tasterima, pomoću kojih se na jednostavan i brz način mogu koristiti funkcije ovih programskih paketa (slika 3).

Upisivanje softvera u memoriju kontrolera ostvaruje se na nekoliko načina (u nekoliko modova). Jedan je da se program sastavlja na personalnom računaru, a zatim se prebaci u memoriju kontrolera, odakle se može i očitati [3]. 


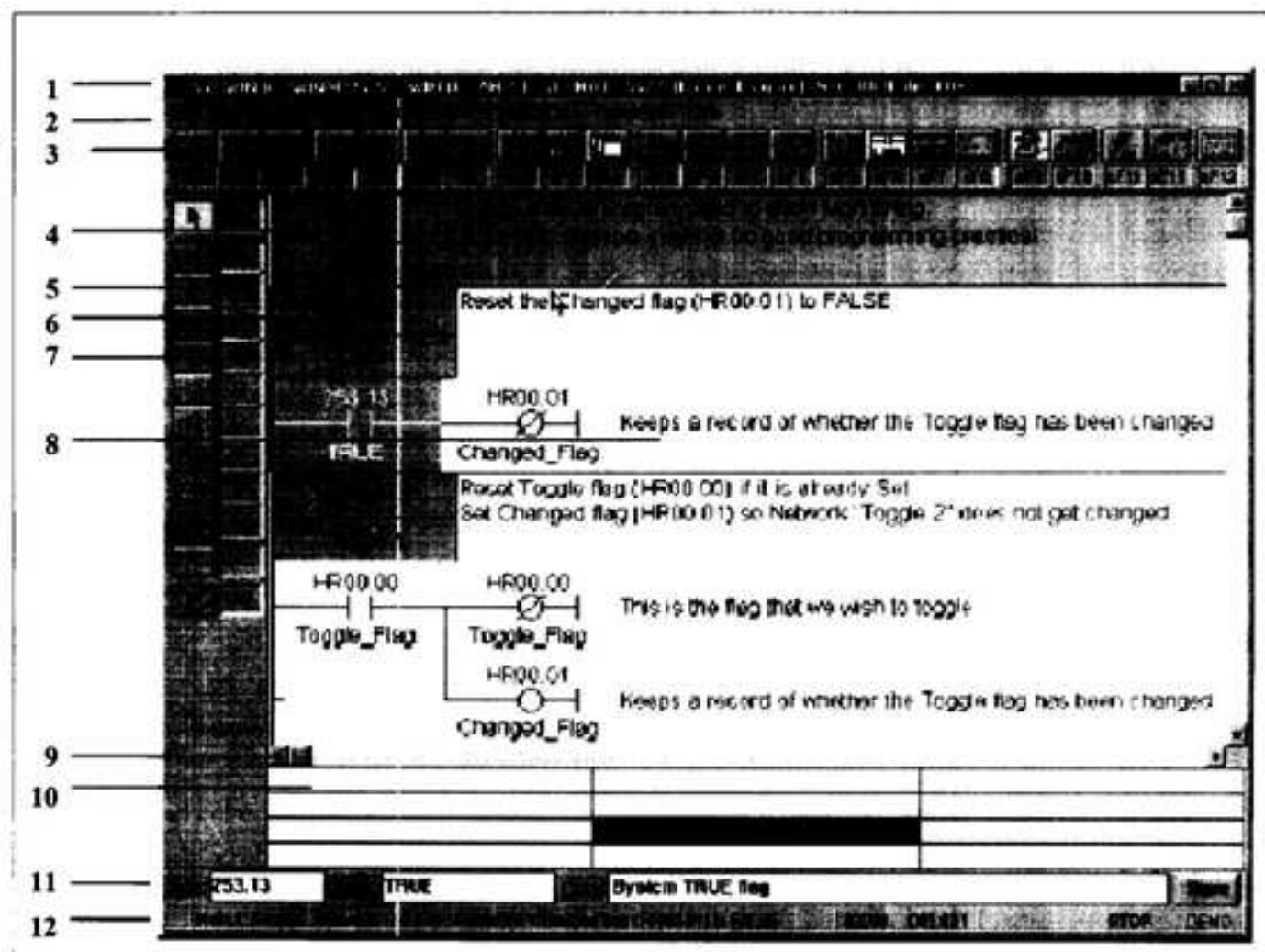

SI. 3 - Izgled ekrana PC pri sastavljanju programa za PLC:

1 - naziv WIN programa, 2 - osnovni meni, 3-podmeni i ključevi, 4 -program 1,5-alati za crtanje, 6 - mreža 1, 7 - kljuðevi alata za crtanje (ili tzv. F ključevi), 8 - radni prostor za pisanje programa, 9 - red za pomicanje prozora, 10 - polje za podatke,

11 - polje za adresu, 12 - polje (red) za pomoc i prikazivanje statusa

Ovaj način predstavlja programski mod, koji može biti aktivan $\mathrm{i} u$ toku rada kontrolera. Pored ove vrste rada (moda) postoji i nadzor rada kontrolera, odnosno monitorski mod, u kojem je moguće nadgledati izvršenje programa, uz ručno postavljanje određenih uslova. Moguce je napraviti listu adresa nad čjim ce se sadržajem izvršiti određena operacija, uz istovremeni pregled (monitoring) većeg broja bitova i reči, što omogućava efikasno otklanjanje grešaka u programu (debugging). Konačno, nakon upisivanja programa u memoriju programabilnog kontrolera, sistem se može pokrenuti (raditi u RUN modu). Pored izbora tipa kontrolera, ovaj programski paket ima mogućnost programiranja kontrolera na početku za rad u različitim tipovima mreža. Moguće je postaviti parametre (set-up) za standardne serijske komunikacije i za parametre potrebne za rad kontrolera u Ethernet mreži. Prema potrebi, ovim podacima je moguće pristupiti u bilo kom trenutku. Ove mogućnosti znatno pojednostavljuju integraciju pojedinačnog kontrolera u mrežu na bilo kom nivou uređaja za automatizaciju. Pored alata za sastavljanje programa i komunikaciju sa kontrolerom postoji i veliki broj dodatnih funkcija. Postoje funkcije za otkrivanje grešaka u programu, kao što su skokovi na nepostojeće lokacije, neispravno programirane petlje, nepravilno napisani 
potprogrami ili interapt rutine, itd. Ovi programski paketi pružaju i mogućnost izrade programske dokumentacije u bilo kom obliku: od relejnog dijagrama sa svim komentarima, štampanja liste korišcenih adresa do mnemonickog zapisa.

Važan segment je i način povezivanja PLC i računara [8] pri čemu se može koristiti više standarda za komunikaciju [9]. U konkretnom slučaju primenljivi su TIA/EIA 422-B i TIA/EIA 485 (RS 485), a mogu se koristiti i drugi koji mogu obezbediti pouzdan prenos podataka sa malim brojem linija, na daljine koje su veće od $1 \mathrm{~km}$.

\section{Prikaz traženih funkcija KOPS-a}

Osnovni skup komandi čine komande za način funkcionisanja kompleta (UKLJ. STRELIŠTA, RUČNO, AUTOMATSKI, OCENI, DEBLOKIRAJ) i komande koje se neposredno odnose na uređaje za pokazivanje meta (PODIGNI, SPUSTI), i uređaje za vuču meta (NAPRED, NAZAD, STOJ). Skup signala koji prati izvršavanje komandi i tok programa dolazi sa graničnih prekidač kraja hoda meta, graničnih prekidača kraja hoda kolica za vuču meta, električnog kola za detekciju pogotka i drugih senzora stanja upravljanih uređaja, prikazuje se na prednjoj ploči komandnog pulta. Pored toga, postoji i signalizacija greške u slučaju da se javi nesaglasnost između zadatog i stvarnog stanja.

Uređajima koji su prostorno raspoređeni na vežbovnom poligonu (strelištu) upravlja se sa komandnog pulta. Uređaji za pokazivanje lakih meta (UPLM), uređaji za pokazivanje teških meta (UPTM) i uređaji za vuču lakih meta (UVLM) pokreću mete izvršavajuci zadate komande. Uređaji za pokazivanje meta (UPLM i UPTM) izvršavaju komande za dizanje i spuštanje meta i omogućavaju signalizaciju pogotka, imitaciju vatre cilja i osvetljenje mete. Signalizacija pogotka se obavlja na osnovu signala od inercionog davača koji reaguje na pogodak mete. Na osnovu signala pogotka pali se signalna sijalica na uređaju i meta se spušta dole. Uređaj se $\mathrm{u}$ tom trenutku automatski blokira, $\mathrm{tj}$. onemogućeno je zadavanje drugih komandi dok se sa komandnog pulta ne zada komanda OCENA.

Uređaji UPLM i UPTM imaju iste funkcije, ali im se neznatno razlikuju električne šeme veza bloka releja i elektronike koji je smešten u kućište uređaja (zbog cega se ne mogu međusobno zamenjivati). Na uređaj UPTM mogu se postaviti i druge mete (po obliku, masi i vrsti indikatora pogotka) ako ovaj uređaj može da ih pokreće, kao npr. metu koja predstavlja siluetu helikoptera [5]. Na slici 4 može se videti broj ulaza (signala stanja upravljanog uređaja) i broj izlaza (upravljačkih signala) iz bloka releja i elektronike uređaja, odnosno PLC i funkcije uređaja UPLM i UPTM.

Za uređaje UPLM i UPTM (da bi zamenili postojeći zastareli blok elektro-

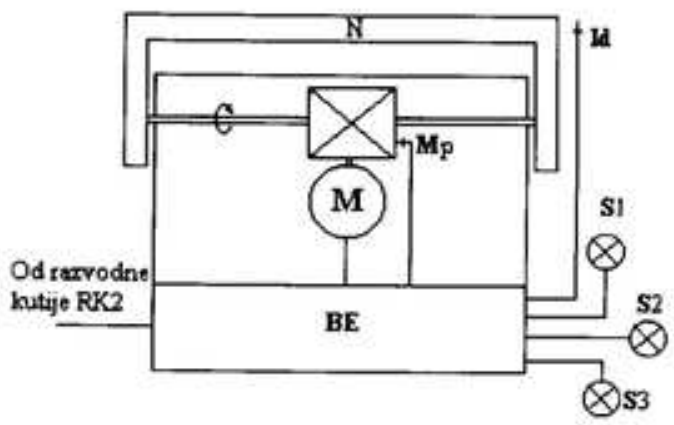

SI. 4 - Blok-šema uredaja za pokazivanje meta UPLM:

BE - blok elektronike i releja (PLC). M - elektromotor, R reduktor, $\mathrm{N}$ - nosac (drzac) mete, Id - inercioni davac pogotka, Mp - mikroprekidae kraja hoda mete, S1 - signalna sjjalica za signalizaciju pogotka, S2 - sijalica za imitaciju efekta vatre cilja, \$3 - reflektor za osvetljenje mete 


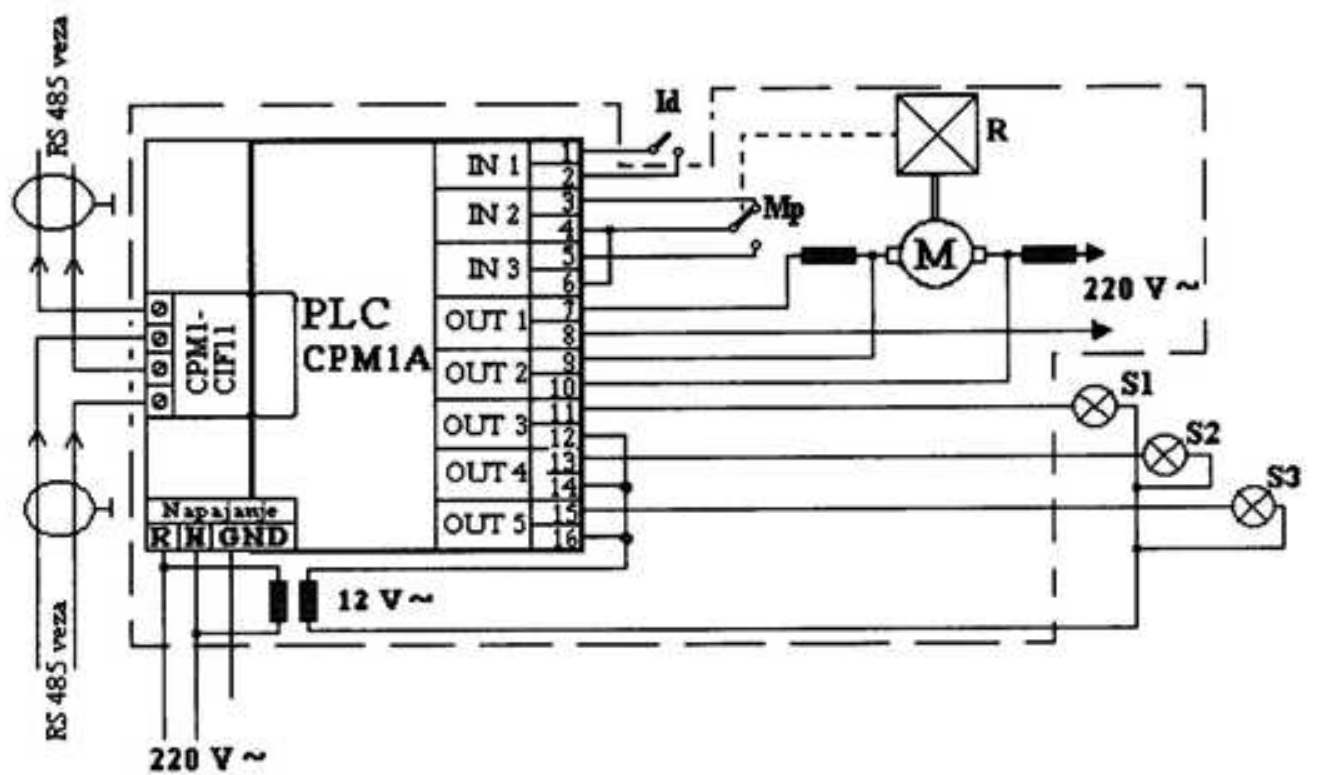

SI. 5 - Princip električne šeme povezivanja PLC u uredajima UPLM i UPTM:

PLC - programabilni kontroler. CPM1-CIFII - konverter RS 485 na spoljni priključak CPM1, Mp - mikroprekidač kraja hoda mete. Id - inercioni davac pogotka, M - elektromotor, R - reduktor, $\mathbf{1} 1$ - signalna sijalica za signalizaciju pogotka, S2 - sjjalica za imitaciju efekta vatre cilja, \$3 - reflektot za osvetljenje mete

nike i releja) potreban je programabilni kontroler sa dva ulaza, pet izlaza (ako se zadrže postojeći releji za elektrodinamičko kočenje potrebna su cetiri izlaza), potrebnim brojem instrukcija za realizaciju komandi koje se prenose sa komandnog pulta, dovoljno memorije za program koji programabilni kontroler treba da izvrši i ima komunikacioni interfejs za povezivanje sa personalnim računarom, odnosno komandnim pultom. Prema ovome i raspoloživom prostoru za ugradnju, kao zadovoljavajuće rešenje može se uzeti minijaturni PLC kakav je CPM1A - 20CDR-A koji proizvodi Omron. On je malih dimenzija i ima 12 ulaznih priključaka i 8 izlaznih priključaka, a može se koristiti onoliko ulaza i izlaza koliko je potrebno. Tipičan broj ulaza i izlaza za ovaj PLC je 10, 20, 30 i 40 sa mogućnošću proširenja do 100 [6].
Princip električne šeme povezivanja PLC prikazan je na slici 5 (na slici nisu navedene originalne oznake priključaka).

Izlazni priključci mogu biti relejni ili tranzistorski sa nezavisnim napajanjem, $\mathrm{s}$ tim što se za uključivanje elektromotornog pogona moraju koristiti posebni uklopni elementi (jer se izlazi ne mogu opterećivati sa više od $0,5 \mathrm{~A})$. Inače, CPM1A ima programsku memoriju od $2 \mathrm{~K}$, memoriju za podatke od $1 \mathrm{~K}, 91$ instrukciju i 28 generatora vremenske baze i brojača sa rezolucijom od $10 \mathrm{~ms}$, što zadovoljava broj sekvenci programa i broj instrukcija po svakoj sekvenci programa za upravljanje uređajima iz sastava KOPS-a. Vreme izvršenja osnovnih instrukcija je $0,72 \mu \mathrm{s}$, sto je znatno iznad potreba da se zadovolji izvršavanje pojedinih sekvenci upravljanja, čije je minimalno trajanje $5 \mathrm{~s}$. 
Iz Uputstva za KOPS [10] može se videti i način povezivanja bloka releja u komandno-razvojnoj kutiji KRK za uređaj za vuču lakih meta UVLM na koji se može postaviti jedan ili dva uređaja UPLM, što omogućava (uz pomoć bloka releja u komandno razvodnoj kutiji KRK) lokalno upravljanje i upravljanje i praćenje funkcije ovog uređaja sa komandnog pulta. Komandama NAPRED, NAZAD i STOJ pokreću se kolica, a na komandnom pultu se signalizira kretanje i položaj kolica: napred, nazad, početak, $k r a j$. Za ovaj uređaj električna Sema povezivanja PLC je jednostavnija. Zahtevaju se dva ulaza (za signalizaciju početka i signalizaciju kraja hoda kolica) i dva izlaza (jedan za pokretanje kolica napred i jedan za pokretanje kolica nazad).

Napajanje uređaja iz sastava KOPS-a ne mora se menjati pri ovoj dogradnji i zameni delova. Inače, napajanje se obavlja preko razvodno-zaštitne kutije RZK, koja ujedno povezuje komandni pult sa ostalim delovima opreme iz sastava kompleta. Dalji razvod napona za napajanje, komandnih signala i signala stanja vrši se preko razvodnih kutija RK1, razvodnih kutija RK2 i komandno-razvodnih kutija KRK. Razvodna kutija RK1 ima šest prikljucaka za uređaje za pokazivanje meta (UPLM i UPTM), dva priključka za uređaje za vuču lakih meta (UVLM) i dva priključka na koje se priključuju kablovi za sledeću razvodnu kutiju. Razvodna kutija RK2 je jednostavne konstrukcije i služi za priključivanje uređaja za pokazivanje meta na RK1. Komandno-razvodna kutija KRK obezbeđuje napajanje, lokalno upravljanje i daljinsko upravljanje uređaja UVLM, a priključuje se na RK1.

\section{Izbor rešenja}

$\mathrm{Na}$ osnovu prikazanih funkcija i razmatranja u okviru definisanja problema i delimične primene postojećeg rešenja (elektromotorni pogon, lokalna signalizacija i imitacija vatre) može se sastaviti algoritam upravljanja, izabrati potreban hardver i sastaviti softver za sistem za upravljanje kompletom opreme pešadijskog strelišta na bazi programabilnih kontrolera i personalnog računara, gde bi se programabilni kontroleri koristili kao prostorno raspoređeni delovi sistema, a personalni računar kao centralna upravljacka jedinica (komandni pult). Ovako rešen sistem za upravljanje ima skromne zahteve u pogledu ožičenja i održavanja, kao i mogućnost memorisanja i obrade velikog broja podataka, što je značajno za zadovoljenje sve većih potreba savremenih vežbovnih poligona. Pored toga, mogu se lako dograđivati i povezati sa drugim sistemima za praćenje, nadzor i upravljanje.

Broj i sadržaj funkcija ovakvog rešenja sistema za upravljanje kompletom opreme za pešadijsko strelište ne samo da može već i mora biti veći od onih koje sada ima KOPS. Pri tome, da bi se pojednostavila njegova upotreba, funkcije ovakvog sistema treba podeliti na tri dela (režima rada). To su: PRIPREMA, RAD I OBRADA REZULTATA.

Deo funkcija sistema PRIPREMA obuhvatio bi samu pripremu za rad, i to: proveru ispravnosti (samotestiranje) sistema i unošenje, ažuriranje i prikazivanje podataka (prostorni raspored meta, program gađanja, imena strelaca i dr.).

Deo funkcija sistema RAD činio bi osnovnu grupu funkcija, kao što su: zadavanje komandi, izvršavanje komandi, signalizacija stanja po zadatoj komandi, sig- 
nalizacija pogotka i registrovanje pogodaka. Ova grupa funkcija, kao i kod postojećeg rešenja, može se izvoditi RUČNO, PROGRAMSKI i po PROGRAMU korak po korak.

OBRADA REZULTATA GAĐANJA obuhvatila bi: obradu broja registrovanih pogodaka primenom standardnih programskih paketa prema postojećim pravilima gađanja, izradu protokola gađanja i sl.

Izbor režima rada (PRIPREMA, RAD, OBRADA) može se rešiti, na primer, preko funkcijskih tastera personalnog računara ili preko grafičkog interfejsa tako što ce se pomeriti oznaka (kursor) na ekranu i poklopiti sa odgovarajućom sličicom sa ispisanim tekstom. Pokretanje programa, aktiviranje neke funkcije ili zadavanje komande sa komandnog pulta može se rešiti preko grafičkog interfejsa ili sa tastature. Svi režimi rada i funkcije moraju biti prikazani graficki, tekstualno i numericki na ekranu u svim režimima rada. Sve opise funkcija upravljačkog sistema treba prevesti u odgovarajući oblik da bi se one mogle i izvršavati. Naime, realizacija digitalnih sistema upravljanja odredene strukture, zadatih funkcija i pravila upravljanja podrazumeva da se elementi arhitekture i programiranja mikroprocesora i mikroračunara, u šta spadaju i razmatrani uređaji, posmatraju kao komponente za izvršenje određenih funkcija u sistemu upravljanja [2].

U praktičnom smislu, ako bi se ovakav sistem realizovao, moraju se slediti pravila za razvoj sistema. To znači da se uradi matematičko-logički opis upravljanog sistema, definišu zahtevi za upravljačke funkcije i sastavi algoritam upravljanja (dijagram toka). Zatim se određuju ULAZI (signali koji odražavaju stanje upravljanog sistema) i IZLAZI (uprav- ljački signali) dislociranih delova i centralnog dela upravljačkog sistema, odnosno određuje konfiguracija hardvera. Nakon upoznavanja opisa funkcija i fizičkog dela sistema (hardver) pristupa se pisanju programa, $\mathrm{tj}$. izradi relejnih šema za programabilne kontrolere, programa za personalni računar kao centralne jedinice i protokola za komunikaciju. Nakon unosa programa u memorije programabilnih kontrolera, koji su odabrani prema broju i vrsti funkcija koje treba da obavljaju i unosa programa u memoriju personalnog računara (ako program već nije na njemu razvijen), preostaje da se još jednom proveri napisani program, da se izvrši simulacija (ako ima uslova), proveri da li su provodnici pravilno priključeni prema utvrđenim i obeleženim brojevima ulaza i brojevima izlaza i, konačno, da se sistem pusti u probni rad.

Na slici 6 data je skica povezivanja uređaja PLC tipa CPM1A sa centralnim uređajem, tj. računarom koji ima ulogu komandnog pulta. Programabilni kontroler CPM1A je malih dimenzija, ima odgovarajući broj ulaza i broj izlaza i nema visoke zahteve za programiranje. Za programiranje se može koristiti programski paket SYSWIN 3.4 ili kompleksniji $\mathrm{Cx}$ Programmer istog proizvođača (Omron).

Konfiguracija hardvera računara bira se prema podacima za programabilni kontroler, broju i složenosti funkcija u pogledu upravljanja i komunikacije, kao i zahteva upotrebljenog programskog paketa za programiranje i rad programabilnih kontrolera. U konkretnom slučaju zahtevi programskog paketa za programiranje programabilnih kontrolera i za rad personalnog računara kao upravljačke jedinice znatno su obimniji od ostalih zahteva, i relevantni su za izbor konfiguracije personalnog računara. Prema ovome, mi- 


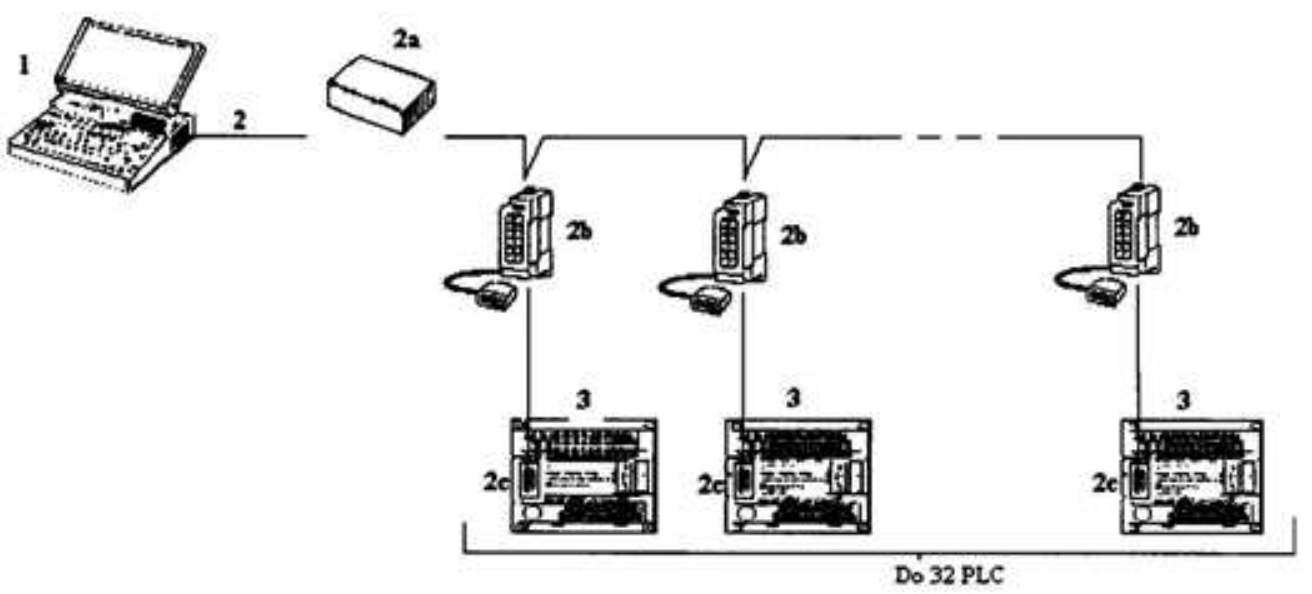

SI. 6 - Skica povezivanja PLC tipa CPM IA na PC:

1 - PC, 2 - RS $232 \mathrm{C}$ kabl, $2 \mathrm{a}$ - konverter RS $232 \mathrm{C}$ na RS 485, $2 \mathrm{~b}$ - konverter RS 485 na spoljni priključak kontrolera, $2 \mathrm{c}$ - spoljni prikljucak kontrolera, 3 - PLC CPM 1 A (strana sa prikljuccima za: napajanje, spoljnu vezu, ulazme signale i izlazne signale)

nimalni zahtevi su da personalni računar ima:

- CPU klase Pentium na učestanosti većoj od $90 \mathrm{MHz}$,

- najmanje 16 MB RAM-a,

- najmanje $40 \mathrm{MB}$ slobodno na $\mathrm{HD}$,

- SVGA rezulucije $800 \times 600$ ili više,

- instaliran MS WINDOWS 95, 98 ili NT 4.0.

Pored toga, za svaki korak programa za programabilni kontroler treba rezervisati još po $1 \mathrm{~K}$ memorijskog prostora na hard disku i RAM memoriji.

Za upravljanje i komunikaciju u personalni računar treba ugraditi odgovarajuću komunikacionu karticu ili odgovarajući adapter za komunikaciju. Prema udaljenosti prostorno raspoređenih uređaja u odnosu na komandni pult moguće je opredeliti se za komunikacioni interfejs i medijum RS 485 (do $1200 \mathrm{~m}$ ) ili neko drugo rešenje (npr. modemsku komunikaciju) za veće daljine.

Što se tiče robustnosti može se izabrati standardna verzija personalnog računara, LAPTOP ili industrijska verzija personalnog računara, već prema uslovima eksploatacije (kabinetski ili terenski).

\section{Zaključak}

Intenzivan razvoj računarske tehnologije i prenosa informacija omogućio je kvalitativno novi pristup problemu upravljanja procesima. Razmatrano rešenje sistema za upravljanje kompletom opreme pešadijskog strelišta (KOPS) na bazi programabilnih kontrolera i personalnog računara (PC), predstavlja savremeni sistem koji zadovoljava ulove za rad prostorno raspoređenih uređaja i u poljskim uslovima, kao i rad komandnog pulta u delimično zaštićenim uslovima (komandna soba, kabina, šator i sl.). Ovo rešenje relativno je jednostavno, a može se brzo realizovati tako što ce se:

- kompletan sistem praćenja i upravljanja razložiti na module;

- komandni pult bazirati na PC, a moduli na PLC i smestiti neposredno uz 
delove procesa (smanjujući troškove ožičenja, povećati pouzdanost funkcionisanja i pojednostaviti održavanje);

- prostorno raspoređenim PLC modulima dodeliti funkcije upravljanja, prikupljanja i obrade ulaznih signala, ažuriranje izlaza, itd.;

- moduli povezati tako da ,komuniciraju" međusobno i sa višim nivoom u hijerarhiji automatizacije procesa, preko jeftinog medijuma (dvožični provodnik);

- ceo sistem projektovati u otvorenoj arhitekturi, uz mogućnost jednostavnog dodavanja modula i njihovog priključenja na magistralu podataka.
Liserafura:

[1] Drndarevic, V.: Akvizicija mernih podataka pomocu personalnog račnara, Mikroelektronika, Beograd 2001.

[2] Stojic, M. R.: Digitalni sistemi upravljanja, Naučna knjiga, Beograd, 1989.

[3] Uputstvo: User Manual - Softwer Programming Tool for OMRON Programmable Logic Controllers, Ver. 3.4. Published Oetober, 1999.

[4] Radosevic, M.: Markiranje i imitacija na vesbama u osnovnoj jedinjci, Vojni glasnik 6/1987.

[5] Rodić, V.: Meta - helikopter, Vojni glasnik 2/1986.

[6] Katalog: Selektion Guide To Programmable Controllers, Omron Cat. No X210-E1-SN, Singapore 1999.

[7] Katalog: Omron katalog proizvoda, Mikrokontrol - Beograd 2001.

[8] Mikrokontrol: Omronov programski paket CX Automation Suite - odgovor novom vremenu, Casopis Mikroelektronika majjun 2001.

[9] Dokic, A.: Uporedni prikaz standarda za prenos podataka, Casopis Mikroelektronika maj/jun 2001.

[10] Dimitrijevic, B. Dudic, S.: Uputstvo kompleta opreme peSadijskog strelista, VojnoizdayaCki zavod, Beograd, 1976. 